\title{
Chapter 17 \\ The Governance of Global Innovation Systems: Putting Knowledge in Context
}

\author{
Christian Binz and Bernhard Truffer
}

\section{Broadening the Governance of Innovation Systems}

In a globalizing knowledge economy, innovation processes increasingly depend on interaction between distant places (Corpataux, Crevoisier, \& Theurillat, 2009). However, most authors of innovation policy literature continue to focus on processes that happen within specific territorial boundaries such as countries or regions. They generally justify their national or regional focus by arguing that science, technology, and innovation policies are typically formulated by national or regional policy makers, or that innovation related governance structures differ substantially between regions and countries. This perspective has been particularly salient in innovation system frameworks, which have become one of the core frameworks to inform innovation policy from a governance perspective (Sharif, 2006). In order to address the challenges of globalization, researchers must thus elaborate a number of conceptual extensions to innovation system approaches. In particular, regionally or nationally embedded innovation processes must be connected to dynamics that emerge from multiscalar actor networks or from the interplay between innovation processes in different spatial subsystems (Martin, 2016; Weber \& Truffer, 2017).

\footnotetext{
C. $\operatorname{Binz}(\bowtie)$

Department of Environmental Social Sciences, Eawag-Swiss Federal Institute of Aquatic Science and Technology, Dübendorf, Switzerland

Centre for Innovation, Research and Competence in the Learning Economy CIRCLE, Lund University, Lund, Sweden

e-mail: christian.binz@eawag.ch; christian.binz@circle.lu.se

B. Truffer

Department of Environmental Social Sciences, Eawag-Swiss Federal Institute of Aquatic Science and Technology, Dübendorf, Switzerland

Copernicus Institute of Sustainable Development, Utrecht University,

Utrecht, The Netherlands

e-mail: B.Truffer@uu.nl
} 
The concept of Global Innovation Systems (GIS) was recently developed to address some of these challenges (Binz \& Truffer, 2017), building on recent contributions in innovation studies whose authors emphasize actor networks and institutional contexts for innovation that are interrelated across spatial scales (Bunnell \& Coe, 2001; Carlsson \& Stankiewicz, 1991). Various analytical approaches have conceptualized the increasing importance of international linkages between and beyond territorial innovation systems (for an overview, see, e.g., Carlsson, 2006; Grillitsch \& Trippl, 2013). However, other scholars have criticized these concepts for remaining rather vague about how supranational actor networks and institutions influence innovation processes and how they differ between different types of sectors and industries (Binz, Truffer, \& Coenen, 2014; Coenen, Benneworth, \& Truffer, 2012; Grillitsch \& Trippl, 2013).

The GIS framework accordingly explicitly specifies how key system resources for innovation are formed in multiscalar networks. In order to grasp the complex spatial configuration of a GIS, two conceptual extensions are proposed. First, subsystems are defined based on the actors, networks, and institutions that generate key system resources (knowledge, market access, financial investment, and technology legitimacy) that are necessary for innovation processes (see Binz, Truffer, \& Coenen, 2016). These subsystems may or may not coincide with territorial boundaries of countries or regions. Second, the overall performance of a GIS depends on whether the relevant subsystems effectively interrelate through so-called structural couplings. These extensions lead to a typology of four ideal-type GIS configurations, distinguishing the industry's dominant innovation modes-STI (science-technology and innovation) versus DUI (doing, using, and interacting) (Jensen, Johnson, Lorenz, \& Lundvall, 2007) - and the economic system of valuation in which markets for the innovation are constructed-standardized valuation in global mass markets versus customized valuation in local contexts (Huenteler, Schmidt, Ossenbrink, \& Hoffmann, 2016; Jeannerat \& Kebir, 2016). Depending on the innovation and valuation mode, the elements of a GIS may be either spatially mobile (with many international spillovers) or rather sticky (with most spillovers constrained to specific regional contexts).

The proposed focus on multiscalar industry dynamics calls for new innovation governance approaches, which require coordination between multiple actors both inside and outside of specific countries or regions. We define innovation governance in line with prior governance and innovation studies as the self-organizing networks, negotiated interorganizational coordination, and decentered, context mediated intersystemic steering that influences the creation, diffusion, and application of novel technologies, products, and services (Benz, Lütz, Schimank, \& Simonis, 2007; Carlsson \& Stankiewicz, 1991; Jessop, 1998). Proponents of innovation system approaches early on implicitly adopted a governance perspective in that they perceived state actors and their innovation policy interventions as only one-if often very important - actor group in broader agentic constellations that jointly shape the directionality of emerging technologies and industries (Weber \& Rohracher, 2012; Weber \& Truffer, 2017). Innovation governance in GIS therefore emphasizes the interplay among different actors who may be active in and across distant territorial subsystems, their transnational networks, as well as the multiscalar institutional structures that may promote, hinder, or shape the trajectory of emerging technologies and industries. In this context, conventional national and regional innovation 
policymakers must reflect on how they intervene in transnational innovation processes, what kind of system resources they mobilize locally or anchor from distant regions, and how actors residing outside their own jurisdictions may be influenced. Furthermore, it also puts in relief what sort of coordinative institutions are needed at a global level that may shape, hinder, or promote new solutions to emerging global challenges. The recent globalization of renewable energy industries highlights the need for such an approach (Binz, Tang, \& Huenteler, 2017). It is probably still fair to say that the topic of global innovation system governance has not received sufficient attention (Truffer, 2012).

In the present chapter, we will formulate a first tentative contribution to the problem of global innovation system governances by elaborating on implications of the multiscalar governance constellations that align with the four innovation system configurations proposed by the GIS concept's supporters (Binz \& Truffer, 2017). The increasing globalization of innovation activity calls one to understand, anticipate, and integrate effects of spatial spillovers in place-based innovation governance strategies. One of this framework's key implications is that the existing focus on the governance of knowledge creation must be complemented with strategies that target "valuation" processes, as in the construction of new markets, the management of technology legitimacy, or the mobilization of financial investment (Jeannerat \& Kebir, 2016).

We will elaborate these arguments as follows. We first review challenges that globalization poses to the existing innovation system literature. In the following section, we introduce the Global Innovation System framework alongside the industrial typology derived from an in-depth assessment of the innovation and valuation dimension. In the section on policy and governance implications of global innovations systems, we elaborate the governance implications for different actors operating at various spatial scales. We then reach a conclusion in the last section and provide a view on how knowledge must be contextualized in order to effectively inform the governance of increasingly globalizing innovation dynamics.

\section{Existing Perspectives on Innovation Systems in Transnational Contexts}

Innovation system scholars emphasize that innovation emerges from complex actor networks that combine complementary knowledge stocks and capabilities into new solutions, all in the context of specific institutional settings (Lundvall, 1992). They utilize a system metaphor to emphasize the distributed yet dynamically coordinated nature of many innovation processes. Positive externalities that emerge from the interaction among universities, firms, policy makers, NGOs, and various intermediaries are a key prerequisite to the innovation process, which can however not be steered or controlled by any actor on his or her own (Nelson, 1993).

Scholars have formulated different variants of the IS concept over the years, including a national (NIS) (Lundvall, 1988), sectoral (SIS) (Malerba, 2002), 
regional (RIS) (Cooke, Gomez Uranga, \& Etxebarria, 1997), and technological (TIS) (Carlsson \& Stankiewicz, 1991) approach. Although each variant emerged from the same roots in innovation studies and evolutionary economics, their developers also created their own research program with a somewhat distinct epistemology and methodological approach (Coenen \& López, 2010). Given these differences, cross-fertilization between the various traditions of IS research has remained surprisingly scant (Weber \& Truffer, 2017). This siloed thinking in the IS tradition has proven to be particularly problematic when trying to formulate a more internationalized perspective on innovation processes. In an international context, the multiscalar overlaps between regional, national, sectorial, and technological elements move center stage. Yet, the existing literature on global, international, or multiscalar IS has generally reflected a lack of integrative thinking in the IS tradition (Carlsson, 2006; Niosi \& Bellon, 1994; Oinas \& Malecki, 2002; Pietrobelli \& Rabellotti, 2009).

The GIS approach builds on recent developments in the TIS tradition and adds more internationalized perspectives from other IS literatures, whose authors recently emphasized the multiscalar actor networks and institutional contexts that jointly support (or hinder) the formation and diffusion of innovation (Jurowetzki, Lundvall, \& Lema, 2015; Oinas \& Malecki, 2002). In some cases, the relevant IS structures may be largely reducible to specific territorial contexts, yet in the majority of cases, they depend on actor strategies, networks, and institutional dynamics that coevolve between different parts of the world. The possible combinations of actors, networks, and institutions that support or hinder innovation in GIS are thus almost countless, and alternative configurations of the systems' structure can lead to similar performance characteristics (Edquist, 1997). As the different system elements become more complexly structured internationally, relating not only to system structures but also to key activities, we propose to focus on the formation dynamics around four distinct system resources-knowledge, market access, financial investment, and technology legitimacy (Binz et al., 2016).

Each of these resources emerge from distributed agency in the system and may each depend on actor networks with specific spatial configurations. For example, a market for a novel technology may not preexist and have to be proactively constructed by firms, prosumers, and intermediaries in specific regions (Dewald \& Truffer, 2012). Similarly, financial investors may only be willing to invest in an innovation after the related industry has been legitimized to some degree and key performance and quality standards have been defined for the related products. Knowledge may be created in an international network of firms, universities, and private R\&D labs, whereas technology legitimacy may depend on the formulation of globally accepted quality standards (like in the ISO process). In this conceptualization, global innovation systems consist of sub-systems that create each of the four necessary system resources and are coupled to each other by multiscalar actor networks and institutional contexts (for a more expansive discussion, see Binz \& Truffer, 2017). 


\section{Analyzing Global Innovation Systems: Introducing Multiscalar Relationships}

To further characterize the spatial configuration of system resource formation processes, we must elaborate two conceptual elements in more detail: (1) subsystems of a GIS and (2) structural couplings between them. In the following, we will elaborate these elements and then propose a heuristic for assessing their spatial configuration.

The notion of subsystems closely relates to the question of where system resources form and which actors are able to access them. We define subsystems not in a spatially predefined way, but as the actor networks and institutions involved in the formation of system resources. Subsystem boundaries can correspond to national or regional borders, but they may also develop in networks that transcend these borders. An emblematic example of multiscalar resource formation processes are those created by dispersed communities of practice, as in the open source software field. Here, actors are often spread globally, but still develop shared cultures, knowledge stocks and investment models that outsiders would find hard to copy and access (Binz \& Truffer, 2017; Lakhani \& von Hippel, 2003). A similar example is innovation in the membrane bioreactor field, which initially emerged from a global R\&D network spanning engineers in French transnational water companies and research institutes in various places around the world (Binz et al., 2014).

In a GIS perspective, the successful creation and diffusion of an innovation ultimately depends on how actors combine knowledge, investment, markets, and legitimacy into new configurations that work. The performance of a given GIS thus depends on (1) whether each system resource is created in a subsystem and (2) whether subsystems are coupled to each other in order to form a coherent global innovation trajectory. Structural coupling here relates to the foundational elements of an IS - actors, networks, or institutions (see Bergek et al., 2015). For example, internationally active firms, international conferences, and trade fairs or an industry's professional culture and quality standards are all examples of coupling domains that may integrate knowledge, market, financial, and institutional elements from various GIS subsystems.

Resource formation and coupling dynamics in GIS are accordingly multipolar and fluid. As key system resources are emerging from subsystems with varying geographies, actors in the GIS will in many cases be unable to directly appropriate a dominant share of them in-house or inside a given region or country. Instead, they will have to create strategic alliances and rely on nongeographic types of proximities to access and anchor a full resource portfolio in a given place (Boschma, 2005). Resourceful actors with a global reach (e.g., transnational companies, global donor organizations, or professional associations) are in a superior position to facilitate effective integration of spatially spread subsystems, but integration may also happen in a specific region with very dense inter-organizational networks, or even in a loosely coupled community of traveling technology experts (Larner \& Laurie, 2010). 
Given this high spatial complexity in any GIS, the question arises of how the generic system configuration may be systematized for different industries. Binz and Truffer (2017) start from the well-established assumption in the sectorial innovation systems literature that differences in an industry's technology characteristics condition the spatial characteristics of the innovation processes (Huenteler et al., 2016; Malerba, 2005). The GIS framework complements this view by emphasizing the coevolution of an industry's knowledge base with capabilities to facilitate institutional and market embedding. The latter concerns in particular processes like market formation, resource mobilization, and technology legitimation, which together define technology valuation, as in the ways in which new products, means of production, and infrastructures are connected to relevant demands and symbolic frames of the customer base. Proponents of the GIS framework therefore propose an industry typology that distinguishes two principal components: characteristics of technological innovation (focusing mostly on knowledge related system resources) and product valuation (related to market formation, the mobilization of financial resources, and legitimacy).

On the technological innovation side, industries can be characterized with regard to whether they subscribe more to a science and technology driven (STI) innovation mode or whether they depend on learning by doing, using, and interacting (DUI) (Jensen et al., 2007). The STI mode is more common in industries with sciencebased, analytical knowledge bases (e.g., biotechnology, pharma, solar PV), whereas the DUI mode characterizes innovation based on engineering-based synthetic knowledge bases (e.g., car manufacturing, machine tools, wind power) (Asheim, Coenen, \& Vang, 2007; Herstad, Aslesen, \& Ebersberger, 2014; Martin \& Moodysson, 2013). STI-based industries rely on scientific principles, which can be codified in models, patents, and reports. Formalized R\&D inside the company, tight industry-university linkages and radical technology breakthroughs characterize these fields (Huenteler et al., 2016). In STI-based industries, knowledge can relatively easily get disembodied and exchanged in space. This industry type will accordingly give rise to significant knowledge spillovers beyond regional and national borders (Moodysson \& Jonsson, 2007; Schmidt \& Huenteler, 2016).

Regarding the characteristics of valuation processes, one may distinguish between standardized and customized valuation systems (Jeannerat \& Kebir, 2016). In the former case, valuation is happening in global mass markets with highly converging user tastes and distribution channels. TV sets, for example, may be produced anywhere and shipped to supermarkets all over the world to cater to very similar user tastes. In customized valuation systems, in contrast, new products will have to be strongly tailored to specialized user preferences that may vary considerably in space. Before an innovation may be sold, the innovation system actors will have to engage in intense user-producer interaction to form new use-patterns, establish socially accepted price-performance relationships, or create reputational capital in the form of brands and labels (Dewald \& Truffer, 2011; Fligstein, 2007). It follows that GIS with standardized valuation systems will create considerable spatial spillovers, whereas customized valuation systems require territorially embedded and thus spatially sticky interaction processes. 
By cross-tabulating these two dimensions, a typology of four ideal-type GIS configurations can be derived (cf. Fig. 17.1). Industries can be roughly positioned in the framework relative to each other, as they often represent different mixtures of innovation and valuation approaches. Also, the position in the typology may depend on the maturation stage of a particular product or industry. These complexities notwithstanding, the four types can be correlated with a characteristic GIS configuration (see Fig. 17.1). The combination of an STI innovation mode and a standardized valuation system will lead to a footloose spatial structure of the GIS with various spillovers inside and between each subsystem. We would therefore expect system resource formation processes to depend on substantial interaction at an international level or to shift rapidly from one region to the next. This setup may be exemplified by the solar PV module industry or by home electronics manufacturing. The combination of a customized form of valuation with a DUI technological innovation mode will-in the other extreme-lead to a spatially rather sticky GIS configuration, with spillovers largely restricted to specific local/regional contexts. This will ultimately lead to strong regional path dependencies and a high variety of customized product variants. Typical examples may be the biogas industry or the housing construction sector. Industries with a DUI-based innovation mode and standardized valuation system can be described as production-anchored GIS types. This setup will create strong and

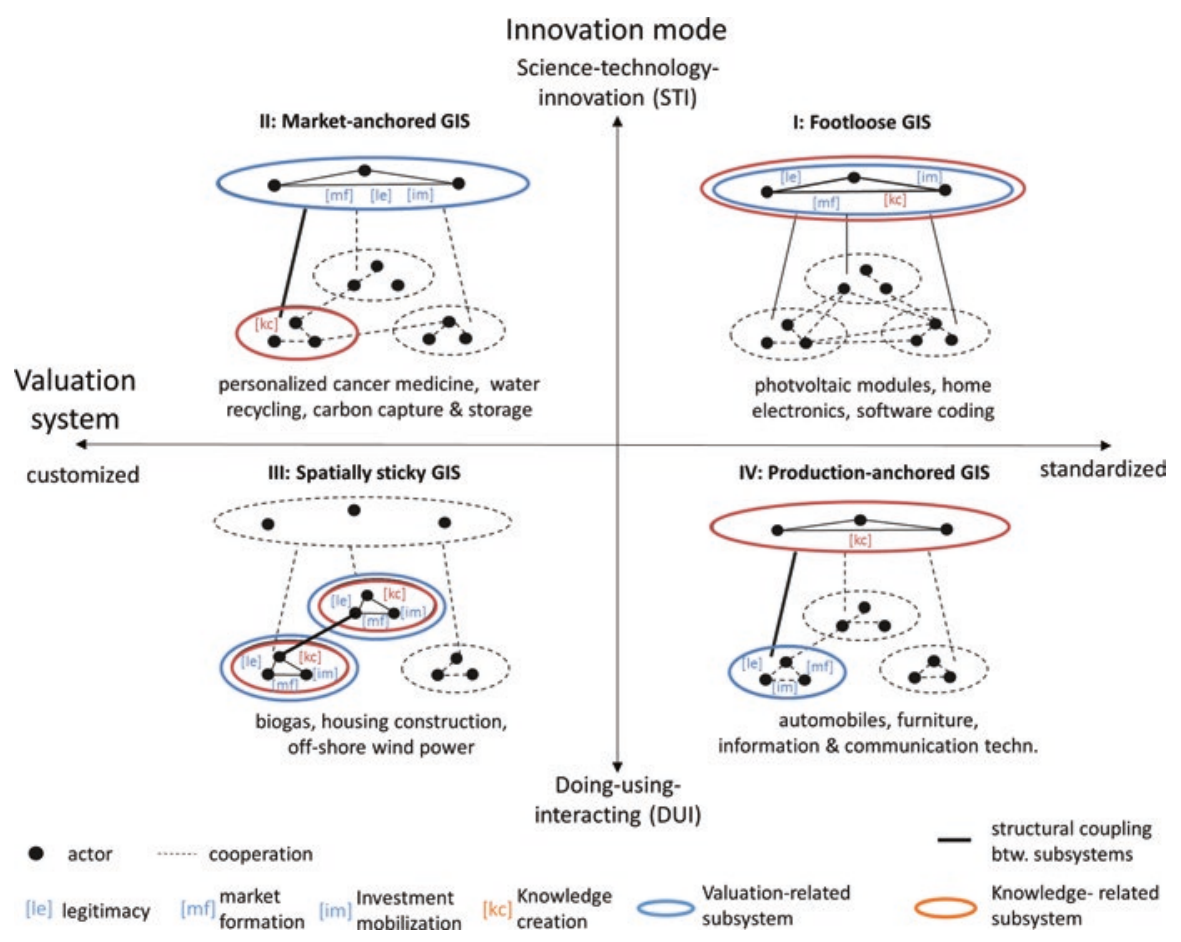

Fig. 17.1 Four ideal-type GIS Configurations. Author's own elaboration, based on Binz and Truffer (2017). Copyright 2017 by Elsevier B.V. Adapted with permission 
persistent geographies of industry leaders managing global value chains to serve global markets. Examples are the automobile industry or information and communication technologies (Lee \& Lim, 2001). Finally, the combination of an STI knowledge base and highly customized markets will create market-anchored GIS structures. This GIS type will often depend on global companies with a strong knowledge base in embedding generic technologies into a variety of local contexts. Examples comprise personalized cancer medicine, but also many civil engineering-based infrastructure services (Moors, Fischer, Boon, Schellen, \& Negro, 2017; Yap \& Truffer, 2019).

The four ideal-type GIS configurations imply radically different governance approaches for all those actors who attempt to shape the innovation process, comprising multinational companies, universities, as well as policy makers in specific regions or countries. It may also apply to intermediary actors like NGOs, civil society groups, or professional associations that have an interest in influencing the directionality of the emerging innovation trajectories. The resulting governance structures of GIS will depend on the interplay between the actors' different strategies. In the following section, we will elaborate some of the implications that the presented typology has for the characteristic governance modes in each GIS type and how they impact strategies of companies, noncommercial, and nongovernmental actors as well as governments at different spatial scales.

\section{Policy and Governance Implications of Global Innovations Systems}

The discussion above implies that innovation governance at a national or regional level should not myopically focus on regionally available assets, but closely reflect the targeted industry's GIS configuration. Industries with a spatially sticky GIS can profit most from conventional innovation governance and policy approaches operating predominantly at regional to national scales, while footloose GISs are most directly challenging traditional governance approaches. Market-anchored and production-anchored GISs in turn challenge specific parts of traditional region- or nation-focused innovation governance paradigms.

\section{Innovation Governance in Spatially Sticky GISs}

In spatially sticky GISs, system resources as well as innovation and valuation dynamics depend on spatial embedding and profit from dense colocation of the relevant actors. For instance, developing the first wind turbines was only possible in a few territorial clusters in Denmark or Germany, which facilitated dense userproducer-intermediary interaction (Garud \& Karnoe, 2003). Similar observations hold for innovation in the biogas industry (Wirth, Markard, Truffer, \& Rohracher, 
2013). In this GIS type, co-creating the first product designs and market solutions in a given region or country continues to provide a sustained first-mover advantage in later stages of the innovation trajectory.

Effective innovation governance for this GIS type thus depends on a territorially specific strategic niche management rationale (Kemp, Truffer, \& Harms, 2000). Producers, users, and various intermediary actors will have to be colocated in a given region and supplied with patient capital ${ }^{1}$ and a (subsidized) market niche in which experimentation, trial \& error, as well as complex learning-by-doing and interacting can occur. In addition, the recombination of preexisting technological capabilities in a gradual, related diversification process will be of key importance (OECD, 2013). The key element providing comparative advantage lies in stimulating continuous interaction between the innovation and valuation side of the industry, thus repeatedly improving the product's main features based on the historically grown industrial specialization and cultural identity of a given region. As such, this approach goes beyond conventional (manufacturing) cluster initiatives, which we would rather relate to the production-anchored GIS type. Structural couplings across different territorial innovation systems are perhaps of lowest importance in this GIS constellation. They may relate to knowledge exchange through mergers and acquisitions or long-term investments in other regions. But essentially, the core system resources are largely available in territories where innovation and valuation actors co-locate.

An emblematic example of the governance challenge for this GIS type is the early wind turbine industry. Garud and Karnoe (2003) observed that the Danish (DUI-based, distributed) bricolage approach to developing wind turbines proved more effective than the American (STI-based, centrally controlled) breakthrough governance approach. Later studies confirmed that the pioneering wind turbine regions in Denmark retained considerable first-mover advantages, even in later lifecycle stages when strong industrial competitors emerged in India or China and when the industry disintegrated its value chain (Lewis, 2007). Having a tightly integrated innovation governance mode proved a locational asset throughout the industry lifecycle, which was characterized by repeated radical innovations in different parts of the product architecture (blades, gearing, turbine control systems, etc.) (Huenteler et al., 2016).

\section{Innovation Governance in Footloose GISs}

The challenges for innovation governance in footloose GIS types directly contrasts the above explanations, as this industry type's innovation system resources emerge in internationally dispersed networks that are hard to locate and retain in any national or regional context. Rather than spatially embedded learning by doing, this

\footnotetext{
${ }^{1}$ Private or state-based financial investments made without expectation of turning a quick profit.
} 
industry type profits from STI-based innovation processes as well as subsidies and trade policies that enable the quick upscaling of manufacturing capacities, as well as price-competitive production for standardized mass markets.

Conceptually, industries with a footloose GIS type can thus best be governed with an STI-based free trade approach: Tax credits, low-interest loans, liberal trade policies, and the creation of centers of excellence in science-based R\&D will all support local firms in accessing internationally available system resources and competing in a fierce global price and quality competition. Patenting, trademarks, and technology standardization will be of decisive importance in this type of innovation process with a dynamic and often noncumulative technology trajectory (Castellacci, 2008). Latecomers in this GIS type may profit from anchoring system resources available elsewhere in order to embark on dynamic catch-up processes (Binz \& Anadon, 2018). Innovation governance actors in developed economies will thus have to anticipate and deal with latecomers leapfrogging to the technological frontier and fast shifts in the global innovation landscape (Lee \& Lim, 2001; Zhu, He, \& Zhou, 2017). We would accordingly expect transnational corporations to be a core actor in this GIS type. They are able to serve global markets and shift the production base quickly between regions according to changing production cost differentials. For national or regional governments, this GIS type implies a rather weak role with an inherent risk of suffering from spill-over effects of national policy efforts.

The experience with the solar PV industry in Germany illustrates how this GIS type challenges conventional, nationally delimited innovation governance approaches. The quite ambitious market deployment subsidy (feed-in-tariff) that Germany introduced in 2002 was aimed at creating a mass market that would provide various actors in the German renewable energy sector with a first-mover advantage (Hoppmann, Huenteler, \& Girod, 2014). Although the policy proved successful in the wind power and biogas sectors, its frictions with the PV sector's footloose GIS configuration quickly became apparent. Given the ubiquitous international structural couplings and spillovers in this GIS type, the subsidized local mass market induced substantial spillovers to latecomers in other places, in particular to China (Quitzow, 2015). Chinese PV firms were particularly skillful in accessing and anchoring markets, knowledge, investment, and legitimation dynamics from other regions in the GIS into a local industrial path that quickly became globally competitive (Binz \& Anadon, 2018). German firms and policy makers were initially not anticipating the disruptive effects of the manifold spatial spillovers to China (Hoppmann et al., 2014), which ultimately led to significant trade disputes with Chinese competitors. The GIS framework suggests that German actors could to some degree have anticipated these global interdependencies and that some sort of international governance scheme would be needed in footloose GISs to regulate the spatially imbalanced costs and benefits of these spatial spillovers. 


\section{Innovation Governance in Market-Anchored GIS}

Market-anchored GISs may in turn profit most from an innovation governance approach that relies on a high-quality lead market rationale: Here, creating pilot applications and successful new market segments for highly demanding customer segments is most decisive for innovation success. In this GIS type, innovationrelated system resources may circulate globally whereas the valuation dynamics will depend on institutional embedding in specific local contexts. Market experience and demonstration effects in one place may thus be turned into a sticky locational advantage that can be mobilized when exporting the product to new places (Beise \& Rennings, 2005).

Conceptually, a governance system that is adapted to this industry type would have to facilitate valuation-side dynamics, for example, in the form of deployment policies, "public procurement for innovation" (Edquist \& Zabala-Iturriagagoitia, 2012), and the close coordination between producers and a local customer base with the highest quality requirements (Porter, 1990). For instance, the culturally diverse movie audience in Hollywood is a key resource for the local film industry for testing the reception of their work in various parts of the world. Rather than supporting basic R\&D or breakthrough innovation locally, a smart governance design would encourage the local industry to access globally available innovative ideas and optimize their (economic/social/environmental) performance in demanding local application contexts. GIS governance structures will therefore have to facilitate pipelines to global knowledge networks while also supporting a locally embedded actor base that experiments with adaptations to the locally specific institutional settings and preference structures. National and regional policy makers might be able to define specific variations in the design of the solutions that are implemented, while simultaneously having to accept the globally predefined core of the technological paradigms.

Examples that illustrate this governance challenge can be drawn from the membrane bioreactor (MBR) or the personalized cancer medicine industries (Binz \& Truffer, 2017; Moors et al., 2017). In the former case, technological innovation emerged from highly internationalized R\&D networks that span various EU countries, Asia, and the USA (Binz et al., 2014). Although various technological designs coexisted for a long time, a key question was where first mass-markets would emerge that would steer the technological trajectory in a specific direction and reduce insecurities and manufacturing prices. US, European, and Chinese actors were the first to create niche markets driven by increasingly rigid water quality standards (Yap \& Truffer, 2019). Given the geographic and institutional particularities in each region's valuation system, the chosen technological configuration and favored technology providers strongly differed between regions (Yang, Cicek, \& Ilg, 2006). The MBR industry is now an oligopoly, dominated by lead firms like GE, Kubota, or Beijing Origin Water that have strongly adapted their valuation strategies to specific market regions. Recently, Chinese firms moved to a leading position based on a targeted valuation-side governance approach. By strongly increasing the 
quality criteria for surface water and standardizing the favored technology designs (based on criteria from local design institutes), a large market for high-quality MBR systems was created in China that could best be served by a local start-up, Beijing Origin Water. These changes in the valuation system enabled Chinese firms to quickly innovate, gain a dominant market position in the high-quality home market, and subsequently export their products to other latecomer countries (Yap \& Truffer, 2019).

\section{Innovation Governance in Production-Anchored GIS}

Finally, the case of production-anchored GIS asks for a cluster- and RIS-based governance approach (Tödtling \& Trippl, 2005), which creates a highly networked, specialized manufacturing base. Here, competitive regional advantages will not predominantly stem from local niche markets, but rather from cumulative synthetic knowledge stocks and culturally embedded cooperation patterns in manufacturing processes. Innovative products will emerge from collective, experience-based competencies in designing complex technical systems. As such, strengthening local knowledge circulation and recombination at the supply side of innovation is more important than supporting market structures, which can also be accessed globally (Boschma, Coenen, Frenken, \& Truffer, 2017).

A governance approach adapted to these challenges would enable informal knowledge exchange in dense industry-supplier-university networks, while also supporting worldwide market access and knowledge exchange. This governance mode may depend on creating intense local knowledge exchange (local buzz) (Bathelt, Malmberg, \& Maskell, 2004) as well as the creation of local cluster organizations, networking events, or business incubators supporting spin-offs from the incumbent industry and universities. Regional actors would have to jointly create applied science organizations with specialized curricula in the respective technological field and support on-the-job and vocational training. At the same time, the regional/national innovation governance structures would have to support exports into global markets with, for example, image campaigns abroad or by investing into trade infrastructure (roads, ports, airports, etc.) and complementary business service industries (market research or logistics). GIS governance actors will thus have to foster regional/national knowledge and skill specializations in global production networks that are often dominated by multinational lead firms.

The car industry illustrates the challenge of this innovation governance model. In terms of valuation dynamics, user tastes have grown highly standardized and gravitate around a few very similar car models. In addition, the manufacturing and supplier networks for cars are globally standardized and organized in highly fragmented value chains (Dicken, 2015). On the innovation side, the car industry provides an emblematic case of spatially sticky innovation system structures. For almost a century, the decisive innovation and design competencies have remained concentrated in the headquarters of the major OEM companies that are in turn embedded in 
policy-supported automotive clusters in Germany, France, Japan, Korea, or the USA (Dicken, 2015). The recent ascent of battery-driven and plug-in hybrid vehicles may challenge this production-anchored GIS structure. Newcomers such as Tesla, BYD, or Google cars are disrupting the sector by introducing more STI-based elements related to digitalization and self-driving capabilities. With an increasing shift toward an STI-based and customized GIS configuration, the traditional innovation clusters in the industry are now forced to build new pipelines to partners in regions with IT-based capabilities. Whether and how governance systems in the traditional car manufacturing clusters will successfully transform to react to this challenge remains an open empirical question (Miörner \& Trippl, 2018) (Fig. 17.2).

This GIS-based innovation governance frameworks provides two interrelated novel contributions. On the one hand, it helps to assess and predict the prevalence of unintended spatial spillovers from national policy interventions, as in the solar PV case. On the other hand, it may be used to identify and eliminate factors that hinder the fast development and diffusion of innovation at supra-national scales, that is, it could be used to expand Weber and Rohracher's (2012) system failure frameworks with a "global policy coordination failure." In the case of solar PV discussed above, erratic regional and national policy support in various parts of the world led to global overcapacities and trade disputes, which now significantly hamper the GIS's capacity to diffuse the innovation. In this GIS type, a global governance structure would in principle be needed that integrates and coordinates innovation dynamics in various parts of the world. Such a governance structure could construct a more level playing field for all involved parties by mitigating trade

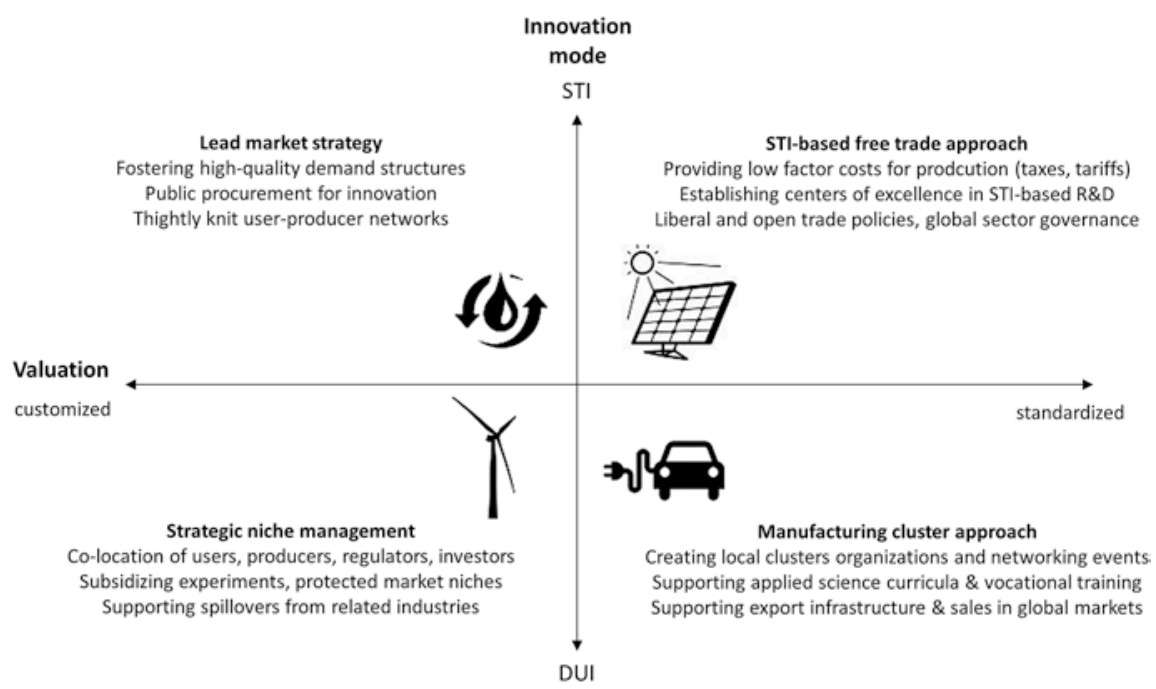

Fig. 17.2 Innovation governance models and policy approaches in each GIS type. Source: Design by authors 
disputes and coordinating policy learning and innovation dynamics in various parts of the world.

\section{Policy and Governance Implications: Putting Knowledge in Context}

In the present chapter, we have elaborated how innovation governance structures have to be reconsidered under conditions of increasingly globalizing industry dynamics. National and regional competition on industrial leadership grows fiercer and more varied than ever, which asks for new ways of overcoming bottlenecks for innovation success. This is all the more important in the context of industry dynamics that address global challenges, such as in "cleantech" or "green" sectors. The dominant governance approaches to this challenge have so far focused on conditions for leveraging knowledge formation and emphasized intellectual property rights and scientific excellence, combined with regional cluster initiatives or smart specialization strategies. We have extended this view by showing that innovation success in some industries depends on being able to anchor extra-regional system resources and addressing valuation processes, that is, the management of emerging markets, the generation of technology legitimacy, or the leveraging of financial resources. Under these conditions, the portfolio of governance mechanisms extends into more procedural or evolutionary options that favor experimentation, the alignment of production capacities with local institutional structures, or the proactive shaping of new industries in the form of lead market strategies.

A key challenge for governing Global Innovation Systems lies in the fact that policies and industry roadmaps are still mostly formulated, legitimized, and executed in territorially bounded contexts. Yet we have shown that in almost all industry types (except for spatially sticky GISs), a sound understanding of internationalized innovation system structures is a key prerequisite for formulating effective regional or national governance schemes and support policies. Simply focusing on local innovation capabilities (e.g., through R\&D support, clusters, RIS, industrial districts, etc.) will not be sufficient. Rather, national or regional governance approaches have to be extended to address actors, institutional contexts, and networks that lie outside their territories. In some extreme cases, supporting the innovative capacity of domestic industries, one might even have to encourage market formation or legitimation processes in distant places (e.g., through cooperation with globally active NGOs and industry associations). In addition, actors may have to consider new governance mechanisms and institutional arrangements that operate at a global level in order to counteract barriers for industry formation if pursued through national policies in isolation. This relates to questions of intellectual property rights, free trade arrangements, the definition of international standards, and the like. In the context of Global Innovation Systems, knowledge for governance therefore means adapting the governance of knowledge to multiple, multiscalar industrial contexts. 
Besides knowledge about producing novel technologies, it is equally important to competently manage social contexts in which these technologies must be embedded and thereby create supportive valuation contexts.

\section{References}

Asheim, B. T., Coenen, L., \& Vang, J. (2007). Face-to-face, buzz, and knowledge bases: Sociospatial implications for learning, innovation, and innovation policy. Environment and Planning C: Politics and Space, 25, 655-670. https://doi.org/10.1068/c0648

Bathelt, H., Malmberg, A., \& Maskell, P. (2004). Clusters and knowledge: Local buzz, global pipelines and the process of knowledge creation. Progress in Human Geography, 28, 31-56. https://doi.org/10.1191/0309132504ph469oa

Beise, M., \& Rennings, K. (2005). Lead markets and regulation: A framework for analyzing the international diffusion of environmental innovations. Ecological Economics, 52, 5-17. https:// doi.org/10.1016/j.ecolecon.2004.06.007

Benz, A., Lütz, S., Schimank, U., \& Simonis, G. (2007). Handbuch Governance: Theoretische Grundlagen und empirische Anwendungsfelder [Handbook governance: Theoretical principles and empirical fields of application]. Wiesbaden: Springer VS.

Bergek, A., Hekkert, M., Jacobsson, S., Markard, J., Sanden, B., \& Truffer, B. (2015). Technological innovation systems in contexts: Conceptualizing contextual structures and interaction dynamics. Environmental Innovation and Societal Transitions, 16, 51-64. https:// doi.org/10.1016/j.eist.2015.07.003

Binz, C., \& Anadon, L. D. (2018). Unrelated diversification in latecomer contexts: The emergence of the Chinese solar photovoltaics industry. Environmental Innovation and Societal Transitions, 28, 14-34. https://doi.org/10.1016/j.eist.2018.03.005

Binz, C., Tang, T., \& Huenteler, J. (2017). Spatial lifecycles of cleantech industries: The global development history of solar photovoltaics. Energy Policy, 101, 386-402. https://doi. org/10.1016/j.enpol.2016.10.034

Binz, C., \& Truffer, B. (2017). Global innovation systems: A conceptual framework for innovation dynamics in transnational contexts. Research Policy, 64, 1284-1298. https://doi.org/10.1016/j. respol.2017.05.012

Binz, C., Truffer, B., \& Coenen, L. (2014). Why space matters in technological innovation systems: The global knowledge dynamics of membrane bioreactor technology. Research Policy, 43, 138-155. https://doi.org/10.1016/j.respol.2013.07.002

Binz, C., Truffer, B., \& Coenen, L. (2016). Path creation as a process of resource alignment and anchoring: Industry formation for on-site water recycling in Beijing. Economic Geography, 92, 172-200. https://doi.org/10.1080/00130095.2015.1103177

Boschma, R. (2005). Proximity and innovation: A critical assessment. Regional Studies, 39, 61-74. https://doi.org/10.1080/0034340052000320887

Boschma, R., Coenen, L., Frenken, K., \& Truffer, B. (2017). Towards a theory of regional diversification: Combining insights from evolutionary economic geography and transition studies. Regional Studies, 51, 31-45. https://doi.org/10.1080/00343404.2016.1258460

Bunnell, T. G., \& Coe, N. M. (2001). Spaces and scales of innovation. Progress in Human Geography, 25, 569-589. https://doi.org/10.1191/030913201682688940

Carlsson, B. (2006). Internationalization of innovation systems: A survey of the literature. Research Policy, 35, 56-67. https://doi.org/10.1016/j.respol.2005.08.003

Carlsson, B., \& Stankiewicz, R. (1991). On the nature, function and composition of technological systems. Journal of Evolutionary Economics, 1, 93-118. https://doi.org/10.1007/BF01224915 
Castellacci, F. (2008). Technological paradigms, regimes and trajectories: Manufacturing and service industries in a new taxonomy of sectoral patterns of innovation. Research Policy, 37, 978-994. https://doi.org/10.1016/j.respol.2008.03.011

Coenen, L., Benneworth, P., \& Truffer, B. (2012). Toward a spatial perspective on sustainability transitions. Research Policy, 41, 968-979. https://doi.org/10.1016/j.respol.2012.02.014

Coenen, L., \& López, F. J. D. (2010). Comparing systems approaches to innovation and technological change for sustainable and competitive economies: An explorative study into conceptual commonalities, differences and complementarities. Journal of Cleaner Production, 18, 1149-1160. https://doi.org/10.1016/j.jclepro.2010.04.003

Cooke, P., Gomez Uranga, M., \& Etxebarria, G. (1997). Regional innovation systems: Institutional and organisational dimensions. Research Policy, 26, 475-491. https://doi.org/10.1016/ S0048-7333(97)00025-5

Corpataux, J., Crevoisier, O., \& Theurillat, T. (2009). The expansion of the finance industry and its impact on the economy: A territorial approach based on Swiss pension funds. Economic Geography, 85, 313-334. https://doi.org/10.1111/j.1944-8287.2009.01035.x

Dewald, U., \& Truffer, B. (2011). Market formation in technological innovation systems: Diffusion of photovoltaic applications in Germany. Industry and Innovation, 18, 285-300. https://doi. org/10.1080/13662716.2011.561028

Dewald, U., \& Truffer, B. (2012). The local sources of market formation: Explaining regional growth differentials in German photovoltaic markets. European Planning Studies, 20, 397-420. https://doi.org/10.1080/09654313.2012.651803

Dicken, P. (2015). Global shift: Mapping the changing contours of the world economy (7th ed.). New York: The Guilford.

Edquist, C., \& Zabala-Iturriagagoitia, J. M. (2012). Public procurement for innovation as mission-oriented innovation policy. Research Policy, 41, 1757-1769. https://doi.org/10.1016/j. respol.2012.04.022

Edquist, C. (1997). Systems of innovation approaches: Their emergence and characteristics. In C. Edquist (Ed.), Systems of innovation: Technologies, institutions and organizations (pp. 1-35). London: Routledge.

Fligstein, N. (2007). The sociology of markets. Annual Review of Sociology, 33, 105-128. https:// doi.org/10.1146/annurev.soc.33.040406.131736

Garud, R., \& Karnoe, P. (2003). Bricolage versus breakthrough: Distributed and embedded agency in technology entrepreneurship. Research Policy, 32, 277-300. https://doi.org/10.1016/ S0048-7333(02)00100-2

Grillitsch, M., \& Trippl, M. (2013). Combining knowledge from different sources, channels and geographical scales. European Planning Studies, 22, 2305-2325. https://doi.org/10.108 0/09654313.2013.835793

Herstad, S. J., Aslesen, H. W., \& Ebersberger, B. (2014). On industrial knowledge bases, commercial opportunities and global innovation network linkages. Research Policy, 43, 495-504. https://doi.org/10.1016/j.respol.2013.08.003

Hoppmann, J., Huenteler, J., \& Girod, B. (2014). Compulsive policy-making: The evolution of the German feed-in tariff system for solar photovoltaic power. Research Policy, 43, 1422-1441. https://doi.org/10.1016/j.respol.2014.01.014

Huenteler, J., Schmidt, T., Ossenbrink, J., \& Hoffmann, V. (2016). Technology life-cycles in the energy sector: Technological characteristics and the role of deployment for innovation. Technological Forecasting \& Social Change, 104, 102-121. https://doi.org/10.1016/j. techfore.2015.09.022

Jeannerat, H., \& Kebir, L. (2016). Knowledge, resources and markets: What economic system of valuation? Regional Studies, 50, 274-288. https://doi.org/10.1080/00343404.2014.986718

Jensen, M. B., Johnson, B., Lorenz, E., \& Lundvall, B. Å. (2007). Forms of knowledge and modes of innovation. Research Policy, 36, 680-693. https://doi.org/10.1016/j.respol.2007.01.006

Jessop, B. (1998). The rise of governance and the risks of failure: The case of economic development. International Social Science Journal, 50, 29-45. https://doi.org/10.1111/1468-2451.00107 
Jurowetzki, R., Lundvall, B., \& Lema, R. (2015). Combining the global value chain and the innovation system perspectives. Paper presented at the DRUID Academy conference, Rebild, Aalborg. Retrieved from https://pdfs.semanticscholar.org/e772/e3fc0f320f4d29b4aa6976bd2 ff23df0a623.pdf

Kemp, R., Truffer, B., \& Harms, S. (2000). Strategic niche management for sustainable mobility. In K. Rennings, O. Hohmeyer, \& R. L. Ottinger (Eds.), Social costs and sustainable mobility: Strategies and experiences in Europe and the United States (pp. 167-188). ZEW Economic Studies: Vol. 7. Heidelberg: Physica. https://doi.org/10.1007/978-3-642-57669-0

Lakhani, K. R., \& von Hippel, E. (2003). How open source software works: "Free" user-to-user assistance. Research Policy, 32, 923-943. https://doi.org/10.1016/S0048-7333(02)00095-1

Larner, W., \& Laurie, N. (2010). Travelling technocrats, embodied knowledges: Globalising privatisation in telecoms and water. Geoforum, 41, 218-226. https://doi.org/10.1016/j. geoforum.2009.11.005

Lee, K., \& Lim, C. (2001). Technological regimes, catching-up and leapfrogging: Findings from the Korean industries. Research Policy, 30, 459-483. https://doi.org/10.1016/ S0048-7333(00)00088-3

Lewis, J. I. (2007). Technology acquisition and innovation in the developing world: Wind turbine development in China and India. Studies in Comparative International Development, 42, 208-232. https://doi.org/10.1007/s12116-007-9012-6

Lundvall, B.-Å. (1988). Innovation as an interactive process: From user-producer interaction to the national system of innovation. In G. Dosi, C. Freeman, R. Nelson, G. Silverberg, \& L. Soete (Eds.), Technical change and economic theory (pp. 349-369). London: Pinter.

Lundvall, B.-Å. (Ed.). (1992). National systems of innovation: Toward a theory of innovation and interactive learning. London: Pinter.

Malerba, F. (2002). Sectoral systems of innovation and production. Research Policy, 31, 247-264. https://doi.org/10.1016/S0048-7333(01)00139-1

Malerba, F. (2005). Sectoral systems of innovation: A framework for linking innovation to the knowledge base, structure and dynamics of sectors. Economics of Innovation and New Technology, 14, 63-82. https://doi.org/10.1080/1043859042000228688

Martin, B. R. (2016). Twenty challenges for innovation studies. Science and Public Policy, 43, 432-450. https://doi.org/10.1093/scipol/scv077

Martin, R., \& Moodysson, J. (2013). Comparing knowledge bases: On the geography and organization of knowledge sourcing in the regional innovation system of Scania, Sweden. European Urban and Regional Studies, 20, 170-187. https://doi.org/10.1177/0969776411427326

Miörner, J., \& Trippl, M. (2018). Embracing the future: Path transformation and system reconfiguration for self-driving cars in West Sweden. European Planning Studies, 27, 2144-2162. https://doi.org/10.1080/09654313.2019.1652570

Moodysson, J., \& Jonsson, O. (2007). Knowledge collaboration and proximity: The spatial organization of biotech innovation projects. European Urban and Regional Studies, 14, 115-131. https://doi.org/10.1177/0969776407075556

Moors, E. H., Fischer, P. K., Boon, W. P., Schellen, F., \& Negro, S. O. (2017). Institutionalisation of markets: The case of personalised cancer medicine in the Netherlands. Technological Forecasting and Social Change, 128, 133-143. https://doi.org/10.1016/j.techfore.2017.11.011

Nelson, R. (1993). National innovation systems: A comparative analysis. New York, NY: Oxford University Press.

Niosi, J., \& Bellon, B. (1994). The global interdependence of national innovation systems: Evidence, limits, and implications. Technology in Society, 16, 173-197. https://doi. org/10.1016/0160-791X(94)90028-0

OECD (Organisation for Economic Cooperation and Development). (2013). Innovation-driven growth in regions: The role of smart specialisation. Paris: OECD. Retrieved from https://www. oecd.org/innovation/inno/smart-specialisation.pdf 
Oinas, P., \& Malecki, E. J. (2002). The evolution of technologies in time and space: From national and regional to spatial innovation systems. International Regional Science Review, 25, 102-131. https://doi.org/10.1177/016001702762039402

Pietrobelli, C., \& Rabellotti, R. (2009). The global dimension of innovation systems: Linking innovation systems and global value chains. In B. Lundvall, K. J. Joseph, C. Chaminade, \& J. Vang (Eds.), Handbook of innovation systems and developing countries (pp. 214-238). Cheltenham: Edward Elgar.

Porter, M. E. (1990). The competitive advantage of nations. Harvard Business Review, 68(2), 73-93.

Quitzow, R. (2015). Dynamics of a policy-driven market: The co-evolution of technological innovation systems for solar photovoltaics in China and Germany. Environmental Innovation and Societal Transitions, 17, 126-148. https://doi.org/10.1016/j.eist.2014.12.002

Schmidt, T. S., \& Huenteler, J. (2016). Anticipating industry localization effects of clean technology deployment policies in developing countries. Global Environmental Change, 38, 8-20. https://doi.org/10.1016/j.gloenvcha.2016.02.005

Sharif, N. (2006). Emergence and development of the National Innovation Systems concept. Research Policy, 35, 745-766. https://doi.org/10.1016/j.respol.2006.04.001

Tödtling, F., \& Trippl, M. (2005). One size fits all? Towards a differentiated regional innovation policy approach. Research Policy, 34, 1203-1219. https://doi.org/10.1016/j.respol.2005.01.018

Truffer, B. (2012). The need for a global perspective on sustainability transitions. Environmental Development, 3, 182-183. https://doi.org/10.1016/j.envdev.2012.05.010

Weber, K. M., \& Rohracher, H. (2012). Legitimizing research, technology and innovation policies for transformative change: Combining insights from innovation systems and multi-level perspective in a comprehensive 'failures' framework. Research Policy, 41,1037-1047. https:// doi.org/10.1016/j.respol.2011.10.015

Weber, M., \& Truffer, B. (2017). Moving innovation systems research to the next level: Towards an integrative agenda. Oxford Review of Economic Policy, 33, 101-121. https://doi.org/10.1093/ oxrep/grx002

Wirth, S., Markard, J., Truffer, B., \& Rohracher, H. (2013). Informal institutions matter: Professional culture and the development of biogas technology. Environmental Innovation and Societal Transitions, 8, 20-41. https://doi.org/10.1016/j.eist.2013.06.002

Yang, W., Cicek, N., \& Ilg, J. (2006). State-of-the-art of membrane bioreactors: Worldwide research and commercial applications in North America. Journal of Membrane Science, 270, 201-211. https://doi.org/10.1016/j.memsci.2005.07.010

Yap, X., \& Truffer, B. (2019). Shaping selection environments for industrial catch-up and sustainability transitions: A systemic perspective on endogenizing windows of opportunity. Research Policy, 48, 1030-1047. https://doi.org/10.1016/j.respol.2018.10.002

Zhu, S., He, C., \& Zhou, Y. (2017). How to jump further and catch up? Path-breaking in an uneven industry space. Journal of Economic Geography, 17, 521-545. https://doi.org/10.1093/ jeg/lbw047

Open Access This chapter is licensed under the terms of the Creative Commons Attribution 4.0 International License (http://creativecommons.org/licenses/by/4.0/), which permits use, sharing, adaptation, distribution and reproduction in any medium or format, as long as you give appropriate credit to the original author(s) and the source, provide a link to the Creative Commons license and indicate if changes were made.

The images or other third party material in this chapter are included in the chapter's Creative Commons license, unless indicated otherwise in a credit line to the material. If material is not included in the chapter's Creative Commons license and your intended use is not permitted by statutory regulation or exceeds the permitted use, you will need to obtain permission directly from the copyright holder.

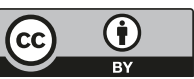

